\title{
Columns in Pharmaceuticals: For Primers
}

\author{
Sanjay Sharma1, Manish Sisodiya1, Rupesh Kumar Gautam ${ }^{2, \star}$, Swapnil Goyal ${ }^{3}$ \\ ${ }^{1}$ School of Pharmacy and Technology Management, SVKM'SNMIMS, Shirpur, Maharashtra, INDIA. \\ ${ }^{2}$ Department of Pharmacology, MM. School of Pharmacy, Maharishi Markandeshwar University Sadopur-Ambala, Haryana, INDIA. \\ ${ }^{3}$ BR Nahata College of Pharmacy, Mandsaur University, Mandsaur, Madhya Pradesh, INDIA.
}

\begin{abstract}
Chromatographic processes have a crucial role in the manufacturing of pharmaceuticals, bio-pharmaceuticals, polypeptides, proteins, enzymes and antibodies. They are apprehended, purged and elegant by size exclusion, ion exchange, reverse phase, hydrophobic interaction or the affinity chromatographic processes. The key to the proper selection of column is the knowledge of the principles of the chromatographic process (HPLC, lon exchange, size exclusion, gas chromatography, UPLC). A Chromatographic column is a tool used for the separation of various chemical compounds in mixtures. A chromatographic column comprises the stationary phase, letting the mobile phase to go from it. Chromatography columns of the various classes are used in gas and liquid chromatography. Make certain robustness and reproducible performances of column, columns are needed to be qualified in an acceptable fashion before each use. This article describes the column specification and enables the reader or industrial primers to make the sense of the many parameters in details such as particle size, dimensions, surface area, pore size, carbon load which is used to describe HPLC columns, ion-exchange chromatography columns, size exclusion columns, chiral columns, gas chromatographic columns and UPLC chromatographic columns with application.
\end{abstract}

Key words: Column, Specifications, HPLC, Size exclusion, Gas chromatographic, UPLC, Bonded Phase.

\section{INTRODUCTION}

The column is a vital component of the chromatography as separation of the components of sample is reached when these separated components pass through from the column. ${ }^{1}$ Column is referred as the heart of various liquid chromatographic separation processes. Stable, high performance column is essential requisite for rugged and reproducible method. Guard column provides protection to analytical columns as it is an essence of process. This is also as artificial top of the main important analytical column. ${ }^{1-3}$ Guard column acts as the final filter both chemical and mechanical. It performs the function of removing debris and can absorb undesirable sample components as well, the sample components that might possibly bring a change into the stationary phase of the analytical columns and the preparative columns by irreversibly binding to it. ${ }^{4-6}$

\section{Dimension of Column}

Column dimensions affect the speed of an analysis and the efficiency sensitivity. The choice of selection of column dimensions largely depend on the chromatographic application; number of analytes in the mixture, analytical, semi-preparative, preparative etc. The primary dimensions of column are size of particle, length, internal diameter, surface are and the carbon load.

\section{Particle size}

For selection of appropriate particle size further criteria should be taken into consideration for achieving more efficient peak. Smaller diameter particles (3-4 $\mu \mathrm{m})$ are used for compound mixtures with
Submission Date: 09-04-2020; Revision Date: 16-07-2020; Accepted Date: 17-08-2020

DOI: 10.5530/ijper.54.3s.140 Correspondence: Dr. Rupesh Kumar Gautam Department of Pharmacology, MM School of Pharmacy, Maharishi Markandeshwar University, Ambala-Chandigarh Highway, Sadopur-

Ambala-134007, Haryana, INDIA.

Phone: $+91-9413654324$

E-mail: drrupeshgautam@gmail. com

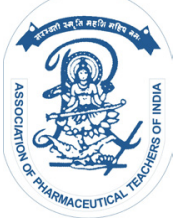

www.ijper.org 
matching components and high throughput separations. Larger diameter particles $(5-10 \mu \mathrm{m})$ are used for regular analyses where analytes have larger structural variations. Particles having diameter greater than $10 \mu \mathrm{m}$ is used for preparative HPLC. 1,3,6,7

\section{Column Length}

Increasing resolution and efficiency is obtained by Longer columns $(250-300 \mathrm{~mm})^{7}$. Whereas low backpressures and short run times are given by short length of columns $(30-50 \mathrm{~mm})$ and are absolutely perfect for gradient analyses. ${ }^{8,9}$

\section{Column internal diameter}

The most common column I.D. is $4.0-4.6 \mathrm{~mm}$. and have optimum flow rate 1.0 to $1.25 \mathrm{~mL} / \mathrm{min}^{7}$ Narrow columns (2.0 to $3.0 \mathrm{~mm}$ ) have optimum flow rates of 0.2 $0.6 \mathrm{~mL} / \mathrm{min}$, which reduces mobile phase consumption and improves sensitivity. 8

\section{Pore Size}

The smaller the pore size, the larger the surface area. Small sample molecules are analyzed by $80-150 \AA$ pore size particles. ${ }^{7}$ Large sample molecules (peptides, proteins and other macromolecules are analyzed by 300-1000 A pore size. Small pore size distribution will increase the column performance. ${ }^{7,8}$

\section{Particle size}

Small particles (3-4 $\mu \mathrm{m})$ are chosen for complex mixtures with similar components. Large particles $(5-10 \mu \mathrm{m})$ are chosen for sample with structurally different compounds. Very large particles $(15-20 \mu \mathrm{m})$ are chosen for preparative separations. ${ }^{7,9}$

\section{Surface area}

High surface area is chosen for more capacity, greater resolution and longer retention. Low surface area packing's are chosen for quick equilibrium time. ${ }^{7}$

\section{Carbon load}

High carbon load are chosen for greater column capacities and resolutions. Low carbon load are chosen for fast analysis times. ${ }^{7}$

Column specifications of various types and configuration of the column (particle, size, length, ID) depend on the separation required. ${ }^{7,8}$ Therefore before method development basic information about column specifications and its performance must be known:

- Plate number $(\mathrm{N})$ of a given value of $\mathrm{k}$

- Peak asymmetry number $A_{s}$

- Selectivity $(\alpha)$ value of two distinguished solutes

- Retention (k) and reproducibility. ${ }^{7,10}$

\section{Column Selection}

Column selection is based on knowledge of the sample and on the expectation of how the analytes will physically and chemically interact with the packing material. Particle size and column dimensions are optimized after obtaining a separation and establishing that the analysis is robust (stable). The column should allow leak-free operation at pressure from 0 to $40 \mathrm{MPa}$ (400 $\left.\mathrm{kg} / \mathrm{cm}^{2} / 6000 \mathrm{psi}\right)$, but typically the inlet pressure does not exceed $20 \mathrm{MPa}$. Most silica-based columns can be operated under these pressures. In general, modular columns are less expensive than conventional columns since the end-fittings are purchased separately and can be reused many times. ${ }^{7}$

The packing material is retained in the column by porous stainless steel or poly ether ketone (PEEk) frits. PEEK frits reduce the degree of irreversible adsorption of metal- complexing agents. Typically, the pores in the frits are at least two-fold smaller than the mean particle size of packing, because frit replacement requires opening the column, the column should be protected with a guard column or inline frit filter. Protection of column is very important with $5 \mu \mathrm{m}$ packing's and is crucial with $3 \mu \mathrm{m}$ or smaller particles. Guard columns collect sample components that are very strongly retained or irreversibly absorbed by the packing material. Pre-column filters remove particles generated by pump and seal wear or present in the mobile phase or sample. The frit in a pre-column filter should have pores the same size or smaller than those in the column frit. In addition, the mobile phase should be filtered to remove small particles that can clog the column inlet frit. Mobile phases for use with $3 \mu \mathrm{m}$ columns typically are filters with $0.2 \mu \mathrm{m}$ membrane; a $0.45 \mu$ membrane can be used with mobile phases for $5 \mu \mathrm{m}$ columns. Samples also must be filtered before injection onto the column. The filter membrane must be resistant to the sample solvent and minimize sample hold-up due to void volume and adsorption. ${ }^{7}$

\section{Classification of Column Phases According to the Different Modes of Chromatography}

\section{High Pressure Liquid Chromatography (HPLC)}

HPLC sections are typically stuffed by pellicular, or permeable particles. Pellicular particles produced either using polymer or a glass dots which are encompassed of a thin equal layer of polystyrene-divinyl-benzene and silica engineered gum, alumina, or other kind of particle trade pitch. The distance across of the pellicular globules is somewhere around 30 and $40 \mu \mathrm{m}$. Permeable particles are all the large ordinarily utilized and have measurements between range 3 to $10 \mu \mathrm{m}$. Plate number 
of well Packed HPLC column base on particle size and length of column given in Table 1.

The Permeable particles are generally made up of, polystyrene-divinyl-benzene, silica engineered pitch, alumina, or other kind of particle trade tar. Silica is most widely recognized kind of permeable molecule pressing material. ${ }^{1,2,7,8,11}$

\section{Normal Phase Chromatography (NPC)}

In a normal phase chromatography technique, retention is controlled by the inter-action between polar parts of stationary phase and solute, the packing of the column should be more polar than compared to that of the mobile phase in respect to the used sample for a column to occur in a normal phase. For this reason the stationary phase used is generally of made up of silica and the classic mobile phases are as follows hexane, methylenechloride, diethyl ether, chloroform and the mixtures of all these. The Si column for normal phase given in Figure 1. The most common phase of column (Table 2) used are $\mathrm{Si}, \mathrm{CN}, \mathrm{NH}_{2}, \mathrm{NO}_{2}$ and $\mathrm{OH} .1,3,7,8,12,13$

\section{Reverse phase Chromatography (RPC)}

In this technique of reverse phase Chromatography, comparatively packing material which is used is non polar in nature and the solvent used is polar in nature with respect to that of the sample. ${ }^{14}$ The interaction of the solutes non-polar components and the stationary non polar phase results in the retention. Classic stationary phases that are used are generally waxy liquids, nonpolar hydrocarbons orthe bonded hydrocarbons (like $\mathrm{C}_{18}, \mathrm{C}_{8}$, etc.) and solvents that are used are mixtures of materials of polar- aqueous-organic such as acetonitrile-water or methanol-water. The most common bonded phase for column are $\mathrm{C} 1, \mathrm{C} 2, \mathrm{C} 3, \mathrm{C} 4, \mathrm{C} 5, \mathrm{C} 6, \mathrm{C} 8, \mathrm{C} 18, \mathrm{CN}_{2} \mathrm{NH}_{2}$ $\mathrm{NO}_{2}, \mathrm{OH}, \mathrm{C}_{6} \mathrm{H}_{5}$ Phenyl-Hexyl with specification and application given in Table 3. ${ }^{9,10,15}$

\section{Common Bonded Phases for Liquid Chromatography}

Common bonded phases ( $\mathrm{Si}, \mathrm{CN}$ and $\mathrm{NH}_{2}$ ) for normal and reversed phase liquid chromatography given in Figure 1-3.

\section{Supercritical Fluid Chromatography}

The principle of Supercritical Fluid Chromatography is similar to the principle of technique of liquid chromatography; however carbon dioxide is typically used as the main mobile phase in SFC. ${ }^{16}$ SFC is basically a type of normal phase chromatography, having high efficiency and speed which is because of its mobile phase that is used. ${ }^{1,2}$ As a supercritical fluid or high pressure liquid, uses solvents that are smart such as $\mathrm{CO}_{2}$ for its properties like high degree diffusivity and low viscosity

\section{Table 1: Plate Number of Well Packed Hplc Column.}

\begin{tabular}{|c|c|c|}
\hline $\begin{array}{c}\text { Particle } \\
\text { diameter }(\boldsymbol{\mu m})\end{array}$ & $\begin{array}{c}\text { Column } \\
\text { length }(\mathbf{c m})\end{array}$ & Plate number $(\mathbf{N})$ \\
\hline 10 & 15 & $6000-7000$ \\
\hline 10 & 25 & $8000-10000$ \\
\hline 5 & 10 & $7000-9000$ \\
\hline 5 & 15 & $10000-12000$ \\
\hline 5 & 25 & $17000-20000$ \\
\hline 3 & 5 & $6000-7000$ \\
\hline 3 & 7.5 & $9000-11000$ \\
\hline 3 & 10 & $12000-14000$ \\
\hline 3 & 15 & $17000-20000$ \\
\hline
\end{tabular}

Table 2: Specifications and Applications of Bonded Phases for Normal Phase Chromatography.

\begin{tabular}{|c|c|c|c|c|}
\hline Specifications & Silica (Si) & CN & $\mathrm{NO}_{2}$ & $\mathbf{N H}_{2}$ \\
\hline Column Type & Normal phase & & & \\
\hline Particle Size & $3,5,10,15 \mu \mathrm{m}$ & $\begin{array}{c}3,5,7,10,16 \\
\mu \mathrm{m}\end{array}$ & $5,10 \mu \mathrm{m}$ & $5,9 \mu \mathrm{m}$ \\
\hline Temperature & $60^{\circ} \mathrm{C}$ & $\cdots \cdots$ & $\cdots \cdots$ & $\cdots \cdots$ \\
\hline Pore Size & $120 \AA$ & $100 \AA$ & $100 \AA$ & $300 \AA$ \\
\hline Surface Area & $170,350,400,500,700 \mathrm{~m}^{2} / \mathrm{g}$ & $\begin{array}{c}300,350,400 \\
530 \mathrm{~m}^{2} / \mathrm{g}\end{array}$ & $350 \mathrm{~m}^{2} / \mathrm{g}$ & $350 \mathrm{~m}^{2} / \mathrm{g}$ \\
\hline Length & $50 \mathrm{~mm}, 100 \mathrm{~mm}, 250 \mathrm{~mm}$ & & & \\
\hline Diameter & $4.6 \mathrm{~mm}$ & $4.6 \mathrm{~mm}$ & & $4.6,20 \mathrm{~mm}$ \\
\hline $\mathrm{pH}$ & $2-8$ & $\cdots \cdots$ & $\cdots \cdots$ & $\cdots \cdots$ \\
\hline Application & $\begin{array}{l}\text { Polar compounds } \\
\text { separation }\end{array}$ & $\begin{array}{c}\text { Polar } \\
\text { compounds } \\
\text { separation }\end{array}$ & $\begin{array}{l}\text { separation of compounds } \\
\text { with double bonds / for } \\
\text { aromatic compounds }\end{array}$ & $\begin{array}{l}\text { In Carbohydrate analysis, High } \\
\text { efficiency is ideal for basic conditions } \\
\text { or yheamphoteric detection. High } \\
\text { selectivity for monosaccharide's to the } \\
\text { oligosaccharides }\end{array}$ \\
\hline
\end{tabular}


which is very much wanted and looked for in today's worlds demanding purification laboratories and also the solvent that can sustain longer as they are reused after they are discarded from some other processes. ${ }^{13,17}$ SFC masters at purifying and separating natural products and chiral compounds because it uses solvent in much less quantity, its faster and overall is cost effective and an environment friendly method that leaves behind high pressure liquid chromatography (HPLC) with respect to performance for chiral separations., ${ }^{5,13,17}$

\section{Size exclusion chromatography}

Size exclusion chromatography is widely utilized in the separations of biological components in aqueous phases and polymer components in the organic phases. Molecular size is the basis for the separation of the molecules. Small sized molecules easily penetrate into the pores present within the packing while the larger size molecules only able to penetrate the pores partially. ${ }^{2}$ The large molecules get eluted much before the smaller molecules. A common packing material mostly used for these columns is molecular sieves. One of such common molecular sieve is Zeolites that is used. The most common bonded phase for column are C18 Figure 4. ${ }^{18-20}$ The Specifications and applications of size exclusion chromatography given in Table 4..$^{18,19,21}$

\section{Ion Exchange Chromatography}

In ion-exchange chromatography, the compounds are separated which is based on ionic forces of attraction between compounds carrying charged groups having opposite charge to those charges present on the stationary phase. The separations are done in between a mobile phase, usually water containing small amounts of salts or alcohols and a stationary phase comprised of either basic or acidic fixed sites. The most common

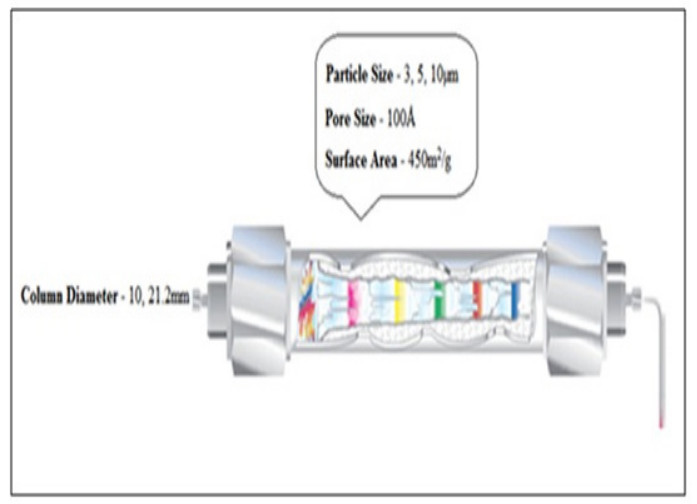

Figure 1: Si column for normal phase.

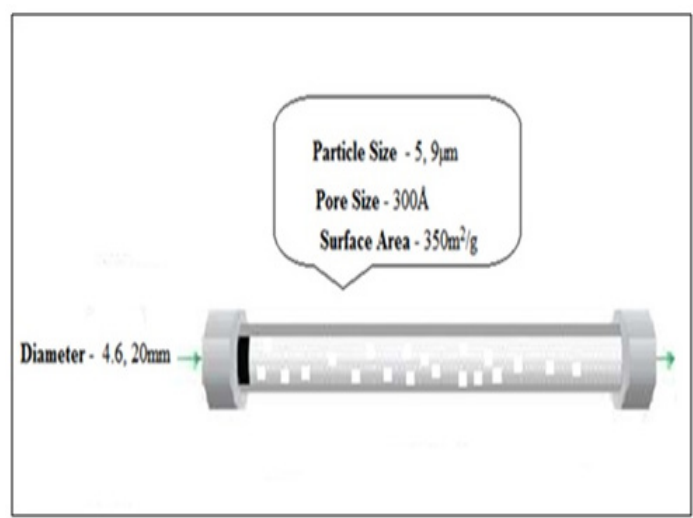

Figure 2: $\mathrm{NH}_{2}$ column for normal phase.

Table 3: Specifications and Applications of Bonded Phases for Reverse Phase Chromatography.

\begin{tabular}{|c|c|c|c|c|}
\hline Specifications & Phenyl-hexyl & $\mathrm{CN}$ & $\mathrm{NO}_{2}$ & $\mathrm{NH}_{2}$ \\
\hline Column Type & Reverse Phase & & & \\
\hline Particle Size & $3,5,7,10, \mu \mathrm{m}$ & $3,5,7,10,16 \mu \mathrm{m}$ & 5,10 & $: 5,9 \mu \mathrm{m}$ \\
\hline \multicolumn{5}{|l|}{ Temperature } \\
\hline Pore Size & $\begin{array}{c}100,120,200 \\
300,350 \AA\end{array}$ & $100 \AA$ & $100 \AA$ & $300 \AA$ \\
\hline \multicolumn{5}{|l|}{ Stationary Phase } \\
\hline Surface Area & $\begin{array}{l}200,300,350 \\
450 \mathrm{~m}^{2} / \mathrm{g}\end{array}$ & $\begin{array}{c}300,350,400,530 \\
\mathrm{~m}^{2} / \mathrm{g}\end{array}$ & $: 350 \mathrm{~m}^{2} / \mathrm{g}$ & $350 \mathrm{~m}^{2} / \mathrm{g}$ \\
\hline \multicolumn{5}{|l|}{ Length } \\
\hline Diameter & $3,4.6 \mathrm{~mm}$ & $4.6 \mathrm{~mm}$ & & $4.6,20 \mathrm{~mm}$ \\
\hline \multicolumn{5}{|l|}{$\mathrm{pH}$} \\
\hline Carbon Load & $8,12,14$ & 7 & & \\
\hline Application & $\begin{array}{l}\text { Has selectivity for } \\
\text { moderately polar } \\
\text { and aromatic } \\
\text { analytes. }\end{array}$ & $\begin{array}{l}\text { very compatible } \\
\text { with LC/MS and is } \\
\text { used for high RP } \\
\text { retention and long } \\
\text { lifetime and }\end{array}$ & $\begin{array}{l}: \mathrm{NO}_{2} \text { phases are suited } \\
\text { for the separation of } \\
\text { compounds with double } \\
\text { bonds or for aromatic } \\
\text { compounds. }\end{array}$ & $\begin{array}{l}\text { It has a higher efficiency for the purpose } \\
\text { of analysis of carbohydrate, Ideal for } \\
\text { amphoteric detection and to the basic } \\
\text { conditions, Higher selectivity for mono- } \\
\text { saccharides to all other oligosaccharides }\end{array}$ \\
\hline
\end{tabular}


bonded phase for column are SAX, SCX, WAX and WCX. . $, 2,-9,11,15,22$ The Specifications and applications of bonded phases for ion exchange chromatography given in Table $5.22-26$

\section{Chiral Chromatography}

In chiral Chromatography, stationary phase comprises of single enantiomers of chiral compound. Separation of chiral molecules is based upon stereochemistry. ${ }^{27}$ We can easily prepare chiral stationary phase by joining a suitable chiral compound to the chiral supports surfaces such as the silica gel, which also creates a Stationary chiral Phase (SCP). Oligosaccharides like cellulose or cyclodextrin (specifically with $\beta$-cyclodextrin, a seven sugar ring molecule) are basis of many common chiral stationary phases. The important specification given in Table $6 .{ }^{17,28,29}$

The most common bonded phase for column are same as normal phase i.e. C1, C2, C3, C4, C5, C6, C8, C18, $\mathrm{CN}, \mathrm{NH}_{2}, \mathrm{NO}_{2}, \mathrm{OH}, \mathrm{C}_{6} \mathrm{H}_{5}$, Phenyl-Hexyl. 7,17

\section{Gas Chromatography}

In gas chromatography technique, the mobile phase which is used is in gaseous form. The application of gas chromatography used in purification and extraction of drugs and others. Columns of Gas chromatography ranges between 1 and 100 meters long. ${ }^{1-2,30,31}$

Gas liquid chromatography (GLC): In the stationary phase, an open tubular (capillary) column adsorbs liquid on its surface, or onto a packed solid material which endorse support in the columns. Stationary phase

\begin{tabular}{|c|c|}
\hline Specifications & $\mathrm{C}_{18}$ \\
\hline \multicolumn{2}{|l|}{ Column Type } \\
\hline Particle Size & $3,5,10,15 \mu \mathrm{m}$ \\
\hline \multicolumn{2}{|l|}{ Temperature } \\
\hline Pore Size & $120,200,300 \AA$ \\
\hline \multicolumn{2}{|l|}{$\begin{array}{c}\text { Stationary } \\
\text { Phase }\end{array}$} \\
\hline Surface Area & $100,200,300,400,450 \mathrm{~m}^{2} / \mathrm{g}$ \\
\hline \multicolumn{2}{|l|}{ Length } \\
\hline Diameter & $4.6 \mathrm{~mm}$ \\
\hline Carbon Load & $7,11,17.5,18.5$ \\
\hline Application & $\begin{array}{l}\text { This columns have an ability of separating } \\
\text { proteins and are effective in separating } \\
\text { molecules like double-stranded DNA } \\
\text { fragments and ribosomal RNA and transfer } \\
\text { RNA. They are excellent in providing fast, } \\
\text { simplified quality control analyses the } \\
\text { molecules of proteins, peptides and other } \\
\text { large-size biopharmaceuticals compounds }\end{array}$ \\
\hline
\end{tabular}

thickness ranges from 0.1 and $8 \mu \mathrm{m}$. The more thickly the layer the more unpredictable the analytes can be. Columns are classified in terms of the type of packing material of tubing and used packing material's type. Generally the dimension for packed columns is $1.5 \mathrm{~m}-$ $10 \mathrm{~m}$ of length and $2 \mathrm{~mm}-4 \mathrm{~mm}$ of internal diameter. Columns are generally composed of inert materials like glass or stainless steel and capillary columns having dimension $0.1 \mathrm{~mm}-0.5 \mathrm{~mm}$ internal diameter and can be $10 \mathrm{~m}-100 \mathrm{~m}$ long. ${ }^{32,33}$ Specification in term of internal diameter, film thickness and polar Phase used given in Table 7 and Table 8 respectively. ${ }^{34-37}$

\section{Capillary columns commonly used in gas chromatography are Generally of three types}

\section{Wall Coated Open Tubular (WCOT)}

The capillaries internal wall is coated (or lined) with a very fine film of a liquid stationary phase. ${ }^{32,38}$

\section{Support Coated Open Tubular (SCOT)}

Wall of capillary tube is covered with a thin solid support layer above which liquid phase gets adsorbed. The SCOT columns efficiency in separation is much higher than that of the WCOT columns this is because

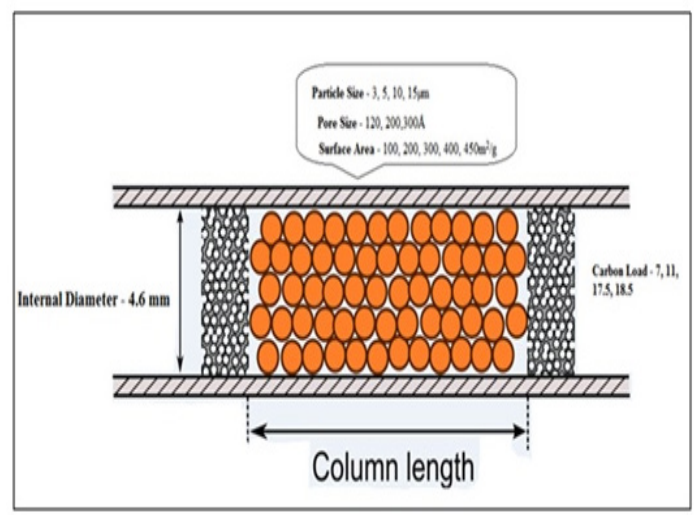

Figure 4: $C_{18}$ size exclusion chromatography column.

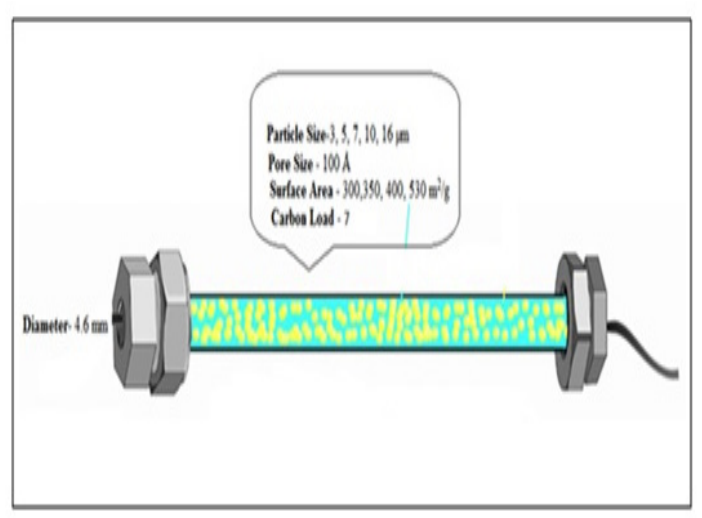

Figure 3: CN column. 
of its surface area which is much more increased of the coated stationary phase. ${ }^{32,38}$

\section{Fused Silica Open Tubular (FSOT)}

Polyimide coating fortifies the walls of capillary fused silica tubes. These capillary columns are flexible, adaptable and can be twisted into coils. ${ }^{32,38}$

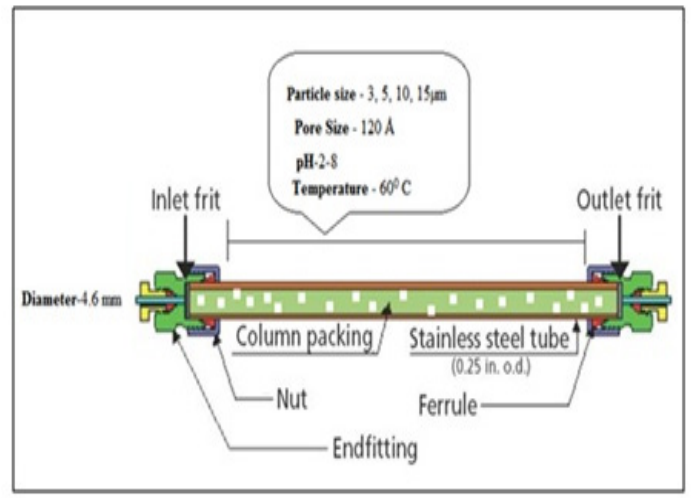

Figure 5: Preparative column.

\section{Packed columns}

In a packed column, separation is obtained by moving the solute particles apart as the carrier gas that is used percolates through the porous bed of column. These columns are composed mainly of two important materials called the stainless steel and the Pyrex glass.

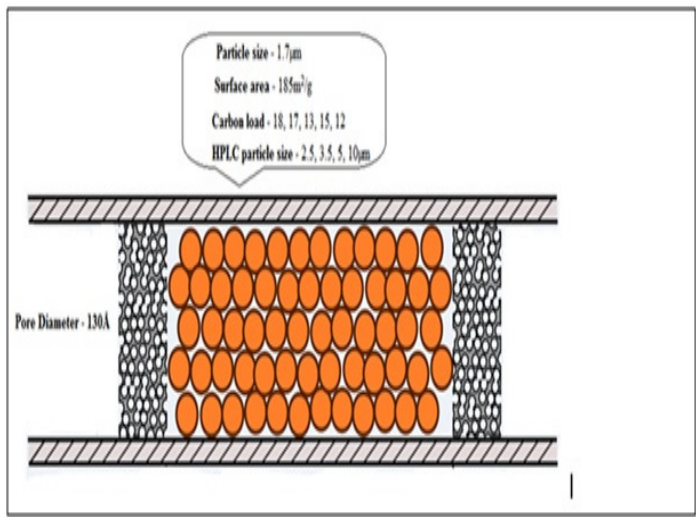

Figure 6: UPLC column.

\begin{tabular}{|c|c|c|c|c|}
\hline Specifications & SAX & $\operatorname{scx}$ & WAX & wcx \\
\hline \multicolumn{5}{|l|}{ Column Type } \\
\hline Particle Size & $5 \mu \mathrm{m}$, & $3,5,10 \mu \mathrm{m}$ & $3,5 \mu \mathrm{m}$ & $5,10 \mu \mathrm{m}$ \\
\hline \multicolumn{5}{|l|}{ Temperature } \\
\hline Pore Size & $100-300 \AA$ & $: 120 \AA$ & $: 120 \AA$ & \\
\hline \multicolumn{5}{|l|}{ Stationary Phase } \\
\hline Surface Area & $170 \mathrm{~m}^{2} / \mathrm{g}$ & $\begin{array}{c}170 \\
350 \mathrm{~m}^{2} / \mathrm{g}\end{array}$ & $300 \mathrm{~m}^{2} / \mathrm{g}$ & \\
\hline \multicolumn{5}{|l|}{ Length } \\
\hline Diameter & $3,4.6 \mathrm{~mm}$ & $3,4.6 \mathrm{~mm}$ & $2.1,3,4.6 \mathrm{~mm}$ & $2,4 \mathrm{~mm}$ \\
\hline Carbon Load & 4 & 4 & & \\
\hline Application & $\begin{array}{l}\text { used for compounds like } \\
\text { that of pharmaceuticals, } \\
\text { pesticides, herbicides, } \\
\text { inorganic anions and } \\
\text { biological species like } \\
\text { the nucleotides and the } \\
\text { glucosinolates }\end{array}$ & & $\begin{array}{l}\text { It issued for simultaneous } \\
\text { separation of acidic, basic and } \\
\text { neutral molecules. The selectivity } \\
\text { is fully controlled by changing } \\
\text { various parameters such as } \\
\text { changing ionic strength, pH, or } \\
\text { organic solvent content that is } \\
\text { used. }\end{array}$ & $\begin{array}{l}\text { Surface of WCX have cation- } \\
\text { exchange terminal which } \\
\text { provides an edge for selectivity } \\
\text { control and rapid mass transfer } \\
\text { which is based on } \mathrm{pH} \text {, for } \\
\text { high-efficiency separation } \\
\text { and moderate capacity of the } \\
\text { column }\end{array}$ \\
\hline
\end{tabular}

\begin{tabular}{|c|c|c|c|}
\hline Specifications & $\begin{array}{c}\text { Poly } \\
\text { (diphenylethylenediamine- } \\
\text { bis-acryloyl) }\end{array}$ & $\begin{array}{l}\text { Poly (trans-1, } \\
\text { 2-cyclohexanediyl- } \\
\text { bis-acrylamide) }\end{array}$ & $\begin{array}{c}\text { Teicoplaninglycopeptide } \\
\text { phase }\end{array}$ \\
\hline \multicolumn{4}{|l|}{ Column Type } \\
\hline Particle Size & $3.5,5 \mu \mathrm{m}$ & $5 \mu \mathrm{m}$ & $3.5,5,10 \mu \mathrm{m}$ \\
\hline Pore Size & $200 \AA$ & $200 \AA$ & $100 \AA$ \\
\hline Surface Area & $340 \mathrm{~m}^{2} / \mathrm{g}$ & $340 \mathrm{~m}^{2} / \mathrm{g}$ & $300 \mathrm{~m}^{2} / \mathrm{g}$ \\
\hline Diameter & $4.6 \mathrm{~mm}$ & $4.6 \mathrm{~mm}$ & $2.1,4.6 \mathrm{~mm}$ \\
\hline Carbon Load & 15 & 5 & 15 \\
\hline
\end{tabular}


Desired shape of Pyrex glass columns are obtained by coiling the glass at about $700^{\circ} \mathrm{C}$. In some cases glass columns are even treated with silanizing reagent to eliminate the hydroxyl groups that are present on its

\section{Table 7: Specifications for Gas Chromatography.}

\begin{tabular}{|c|c|}
\hline Specifications & Sulfur/octyl \\
\hline Internal diameter & $0.18,0.25,0.32,0.53 \mathrm{~mm}$ \\
\hline Film Thickness & $0.25,1,3,4,5 \mu \mathrm{m}$ \\
\hline
\end{tabular}

surface, which becomes active by catalysis and thus produce asymmetric peaks. ${ }^{31}$

\section{Glass Packed Columns}

Phase: 4\% Carbowax 20M +0.8\% KOH, Diameter: 2.0mm, Metal Packed, Phase: 0.2, 10\% carbowax, 20\% sebaconitrile, Diameter: $2.0,2.1 \mathrm{~mm}^{39}$

\section{Preparative Columns}

Preparative columns operate at lower pressure which translates into longer column life. Preparative sized

\begin{tabular}{|c|c|c|c|}
\hline Specifications & Amine & Poly (ethylene glycol) & Poly (alkylene glycol) \\
\hline Internal diameter & $0.53 \mathrm{~mm}$ & 1. $0.25,0.32,0.53 \mathrm{~mm}$ & $0.25,0.32,0.53 \mathrm{~mm}$ \\
\hline Film thickness & $1.5 \mu \mathrm{m}$ & $0.25 \mu \mathrm{m}$ & $0.25,0.50 \mu \mathrm{m}$ \\
\hline Applications & $\begin{array}{l}\text { This base-deactivated column } \\
\text { that is specially prepared is } \\
\text { designed for the analyses of } \\
\text { some amino compounds like } \\
\text { all amines i.e primary amines, } \\
\text { secondary amines and tertiary } \\
\text { amines and other basic } \\
\text { volatile compounds as well. }\end{array}$ & $\begin{array}{l}\text { This column facilitates for robust and } \\
\text { reproducible analysis of compounds } \\
\text { like methyl esters (FAMEs) and fatty } \\
\text { acids specifically the omega } 6 \text { fatty } \\
\text { acids and the omega } 3 \text { fatty acids. } \\
\text { Its tests are conducted to ensure } \\
\text { reproducible FAME, values with } \\
\text { equivalent chain length (ECL) and the } \\
\text { key components resolution. }\end{array}$ & $\begin{array}{l}\text { The space of polarity in between a } 50 \% \\
\text { of column that is phenyl substituted and } \\
\text { a classical column which is a wax-type } \\
\text { column is successfully filled by this } \\
\text { column, because it has slightly lower } \\
\text { polarity than that of a classical wax- } \\
\text { type column. Its the most suited column } \\
\text { for the analyses of compounds like } \\
\text { alcohols. }\end{array}$ \\
\hline
\end{tabular}

\begin{tabular}{|c|c|c|}
\hline \multicolumn{3}{|c|}{ Table 9: Uplccolumn Specification. } \\
\hline Specifications & $\begin{array}{c}\text { Ethylene Bridged Hybrid (BEH) } \\
\text { Particle Technology }\end{array}$ & $\begin{array}{c}\text { Charged surface hybrid } \\
\text { technology }\end{array}$ \\
\hline BEH and CSH & $\begin{array}{c}\mathrm{C}_{18}, \mathrm{RP} 18, \mathrm{C}_{8}, \text { Phenyl, HILIC, } \\
\text { Amide }\end{array}$ & $\mathrm{C}_{18}$, Phenyl-Hexyl, Fluro-Phenyl, \\
\hline Particle size & $1.7 \mu \mathrm{m}$ & $1.7 \mu \mathrm{m}$ \\
\hline Pore Diameter & $130 \AA$ & $130 \AA$ \\
\hline Surface area & $185 \mathrm{~m}^{2} / \mathrm{g}$ & $185 \mathrm{~m}^{2} / \mathrm{g}$ \\
\hline Carbon load & $18,17,13,15,12$ & $15,14,13$ \\
\hline HPLC particle size & $2.5,3.5,5,10 \mu \mathrm{m}$ & \\
\hline
\end{tabular}

\begin{tabular}{|c|c|c|c|}
\hline Specifications & $\mathrm{C}_{18}$ & Phenyl & Amide \\
\hline \multicolumn{4}{|l|}{ Column Type } \\
\hline Particle Size & $3,5,10 \mu \mathrm{m}$ & $5,10 \mu \mathrm{m}$ & $5,10 \mu \mathrm{m}$ \\
\hline \multicolumn{4}{|l|}{ Temperature } \\
\hline Pore Size & $100 \AA$ & $100 \AA$ & $100 \AA$ \\
\hline \multicolumn{4}{|l|}{ Stationary Phase } \\
\hline Surface Area & $450 \mathrm{~m}^{2} / \mathrm{g}$ & $450 \mathrm{~m}^{2} / \mathrm{g}$ & $450 \mathrm{~m}^{2} / \mathrm{g}$ \\
\hline \multicolumn{4}{|l|}{ Length } \\
\hline Diameter & $10 \mathrm{~mm}$ & $10,21.2 \mathrm{~mm}$ & $10,21.2 \mathrm{~mm}$ \\
\hline Carbon Load & 25 & 19 & 19.5 \\
\hline Application & $\begin{array}{c}\text { Excellent retention, Symmetry in peak shape, } \\
\text { High throughput reproducibility, Overall LC- } \\
\text { MS compatibility }\end{array}$ & & \\
\hline
\end{tabular}


columns are available in 21.2, 30 and $50 \mathrm{~mm}$ internal diameters with lengths ranging from $50-250 \mathrm{~mm}$. Columns are available in 5, 10 and $15 \mu \mathrm{m}$ particle sizes (Figure 5) with very high efficiency in every dimension. Moreover, Preparative column have been excellent retention, symmetry in peak shape, high throughput, reproducibility, overall LC-MS compatibility. Utilization of preparative column in both the phases, such as normal phase and reverse phase chromatography. ${ }^{40-42,43}$

\section{UPLC}

UPLC technology provides for improvement of resolutions, sensitivity and the fast analysis speed to be achieved. The aim is to achieve the ultra-fast analysis, enhanced and increased throughput while maintaining the resolution as well as improving resolution along with decreasing the time that is required for analysis or to achieve ultra-high resolution. UPLC column (Figure 6) specification given in Table 9 and Table $10 .{ }^{44}$

\section{CONCLUSION}

The availability of a stable, high performance column is essential in developing a rugged, reproducible method. The purpose of this article is based on the selection of column according identification, separation and purification technique. The different columns can vary in size of particle, pore size, surface area, Plate number, the carbon load and other critical, parameters. In this write up contain information about various column support, stationary phases and column packing which are beneficial for industrial as well as researcher primers in the field of pharmaceutical sciences. The various types of compounds are separated through the columns specification from different types of chromatographic principles. The proper selection of columns helps to separate the compounds with best results of selectivity, resolution peak, tailing factor, HETP without leaching and other extractable.

\section{ACKNOWLEDGEMENT}

Authors are thankful to the management of School of Pharmacy and Technology Management, SVKM'SNMIMS, Shirpur, Maharashtra and Maharishi Markandeshwar University Sadopur-Ambala, Haryana.

\section{CONFLICT OF INTEREST}

The authors have no conflicts of interest.

\section{ABBREVIATIONS}

HPLC: High Performance Liquid Chromatography; UPLC: Ultra Performance Liquid Chromatography;
I.D.: Internal Diameter; PEEK: Poly ether ketone; HETP: Height Equivalent to the Theoretical Plate.

\section{REFERENCES}

1. Snyder LR, Kirkland JJ, Glajch JL. Practical HPLC method development. $2^{\text {nd }}$ ed.; Willy-interscience publication, John Willy and Sons, INC. 1997;174-84.

2. Skoog D, Holler J, Crouch S. Principles of instrumental analysis. $6^{\text {th }}$ ed.; Thomson Brooks/Cole: Belmont. 2007;899-901.

3. Veronika RM. Practical high performance liquid chromatography. $4^{\text {th }}$ ed; John Wiley and Sons. 2004;159-61,183-4, 207-10.

4. Alejandra GP, Barron AR. Principles of Gas Chromatography. Version 1.2. 2014;9:4-39.

5. Weston A, Brown PR. High Performance Liquid Chromatography. 2011;11416.

6. Brown PR, Hartwick RA. High performance liquid chromatography in chemical analysis. John Wiley and Sons: New York. 1989;98:277-95.

7. Sethi PD. High performance liquid chromatography, CBS Publishers and Distributors New Delhi; $1^{\text {st }}$ ed. 2001;69-71, 91.

8. Agilent ZORBAX Column Selection Guide for HPLC, Agilent technologies. 2018.

9. Column Dimensions and Related HPLC Parameters, Waters, Performance Perspective. 2019

10. Kahler TY, Lake R, Kozel S, Wittrig M, Albrigh B, Restek CD. Corporation, Bellefonte, PA, USA; The Hydrophobic-Subtraction Model and ReversedPhase Selectivity: A Simplified Look at Column Phase Selection

11. Agilent-2012, Column Selection Guide for HPLC column. 2012.

12. Waters, The Science of Whats Possible ${ }^{\mathrm{TM}}$, Waters spherisorb column, Care and use Manual. 2019.

13. HICHROM Chromatography Columns and Supplies, Catalogue 9 LC columns Thermo Scientific Columns for Biomolecules.

14. Chemistry, Libretext ${ }^{\mathrm{TM}}$ Chromatographic columns. 2014

15. Cation Exchange Chromatography Workflow Agilent Bio lex HPLC Columns Agilent Bio Mab Hplc Columns, Agilent Technologies. 2019.

16. HPLC Basics Fundamentals of Liquid Chromatography (HPLC), Agilent Technologies.

17. Kristensen K, Angelo HR, Blemmer T. Official Patient Guide to Disease X. J. of Chrom A. 1994;666(1-2):283-7.

18. Size Exclusion Chromatography Principles and Methods, GE Health care Life sciences. 2019

19. Dubey VK. Lecture 5: Size exclusion (Gel Filtration) chromatography, Proteomics and Genomics, IIT Guwahati. 2018.

20. An Introduction to Gel Permeation Chromatography and Size Exclusion Chromatography, PRIMER, Agilent Technologies. 2015.

21. Supelco Ionic Liquid GC Columns, Introduction to the Technology. 2009.

22. Cation Exchange Chromatography Workflow Agilent Bio lex HPLC Columns Agilent Bio Mab Hplc Columns, Agilent Technologies. 2018.

23. Poly SULFOETHYL A ${ }^{\text {TMColumns, PolyLC }}$ INC $_{2008 .}$

24. Thermo Scientific Syncronis Silica HPLC Columns, Thermo Scientific. 2019.

25. Raymond PW, Scott. Introduction to Analytical Gas Chromatography $2^{\text {nd }}$ ed. Ian A. Fowlis; $2^{\text {nd }}$ ed. 2008.1997;27.

26. Robert LG, Eugene F. Barry Modern Practice of Gas Chromatography $4^{\text {th }}$ ed. $2004 ; 76$.

27. Diacel Corporation, CPI Company, chiral columns. 2019.

28. Agilent Zorbax Sax, Datasheet, Agilent Technologies. 2019.

29. Agilent Zorbax 300-SCX, Datasheet, Agilent Technologies. 2018.

30. Krygier K, Sosulski F, Hogge H. Free, esterified and insoluble-bound phenolic acids. 1. Extraction and purification procedure. J Agric Food Chem. 1982;30(2):330-4.

31. Munson JW. Pharmaceutical analysis (Modern Methods) Part A, international medical book distributors, Indian Reprint. 2001;39-44.

32. Agilent $J$ and WGC Column Selection Guide, Speed your selection with this one-stop resource, Agilent Technologies. 2019.

33. Sigma Aldrich, A part of merck, Analytical Chemistry and Chromatographic product. 2018.

34. Supelco lonic Liquid GC Columns, Introduction to the Technology. 2018. 
35. The Ultimate Guide to HPLC/UHPLC Reversed Phase Selectivity, Phenomenex. 2018.

36. ApHera ${ }^{\mathrm{TM}} \mathrm{C}_{18}, \mathrm{C} 8$ and $\mathrm{C} 4$ Polymeric Reversed Phase HPLC Columns. 2006.

37. Reversed-Phase $C_{18}$ Columns (ODS), YMC General Catalog. 2018.

38. Diacel Corporation, CPI Company, Normal phase HPLC columns. 2018.

39. Solid Phase Extraction Application Guide, Macherey-Nagel. 2019.

40. Thermo Scientific Chromatography Columns and Consumables 2016-2017,Thermo scientific. 2016.
41. Sigma Aldrich, A part of merck, Analytical Chemistry and Chromatographic product. 2020

42. Dong MW. Modern HPLC for practicing scientists. Willy-interscience publication. 2006;47-52.

43. Munson JW. Pharmaceutical analysis (Modern Methods) Part A, internationa medical book distributors, Indian Reprint. 2001;39-44.

44. Comparison guide to $\mathrm{C}_{18}$ columns, Reversed phase HPLC analysis,Comparison Data on Commonly Used $\mathrm{C}_{18}$ Phases Stationary Phase Specifications MAC-MOD, Fourth Edition. 2008.

\section{PICTORIAL ABSTRACT}

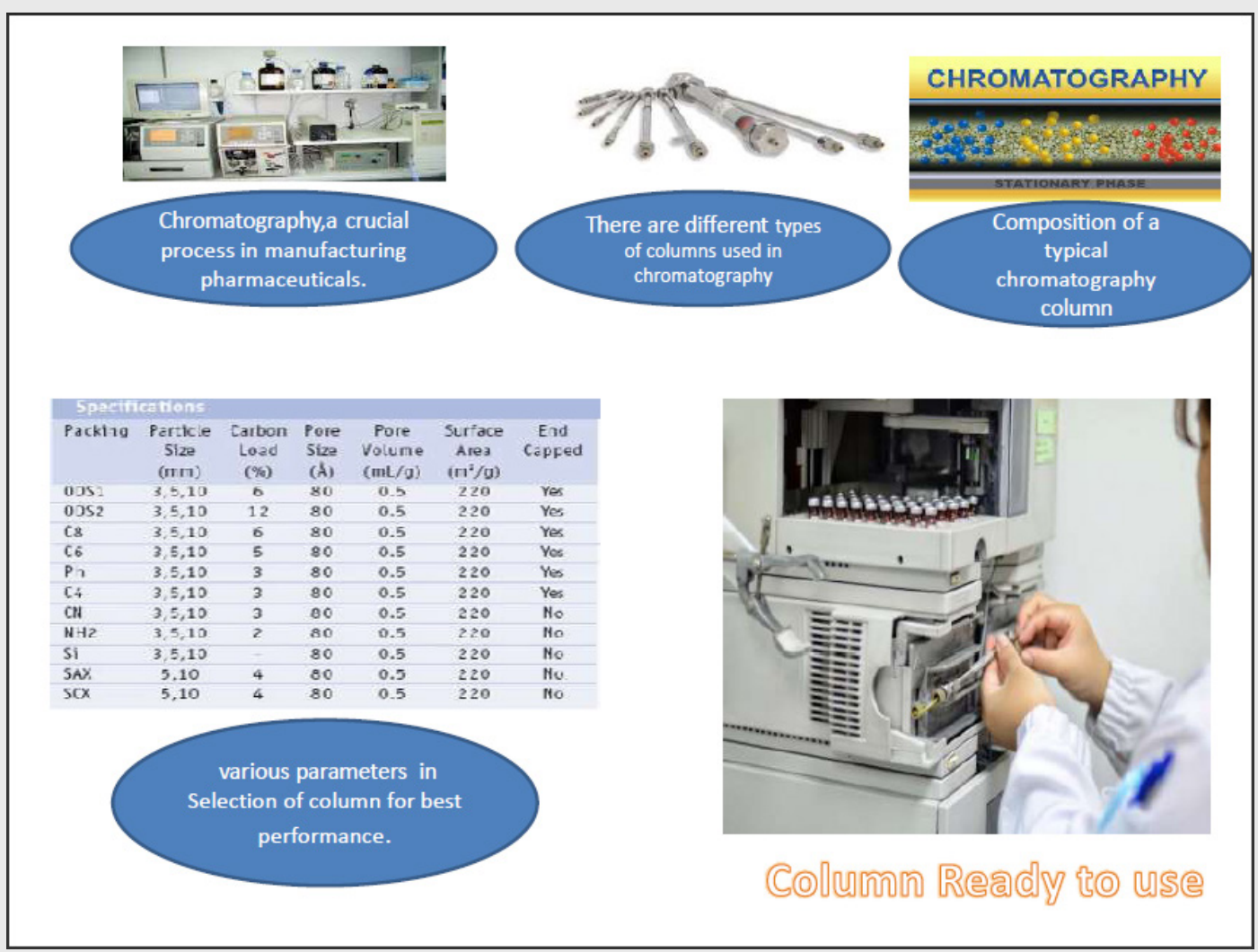

\section{SUMMARY}

This current article describes the column specification and enables the reader or industrial primers to make the sense of the many parameters in details such as particle size, dimensions, surface area, pore size, carbon load which is used to describe HPLC columns, ion-exchange chromatography columns, size exclusion columns, chiral columns, gas chromatographic columns and UPLC chromatographic columns with application. 


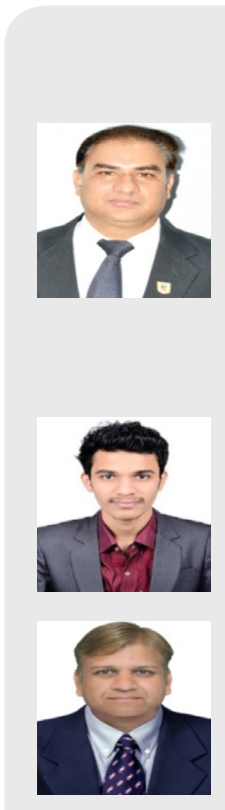

About Authors

Dr. Sanjay Sharma is currently working as Associate Professor and Head, Department of Quality Assurance at School of Pharmacy and Technology Management, SVKM'SNMIMS, ShirpurMaharashtra, India. He is having more than 18 years' experience in research, academics and industry (Analyst Chemist) with strong analytical skills. He granted 02 patent and filed 8 National patents and has more than 68 publication international/national research in peer-reviewed journals (ACS publication, Elsevier, Willy, Taylor, and Francis, Begell House, Bentham, etc.) (Google Scholar Citation: 496, h- index: 12 and i10 - index 15).

Mr. Manish Sisodiya did his B.Pharm from School of Pharmacy and Technology Management, SVKM'SNMIMS, Shirpur, Maharashtra-India. Now he is doing preparations for competitive examinations for his higher studies.

Dr. Rupesh Kumar Gautam is currently working as Professor and Head, Department of Pharmacology, MM School of Pharmacy, MM University, Sadopur-Ambala, Haryana-India. He is having more than 11 years of teaching and research experience. More than thirty research and review articles are in his credit in various journal of repute. He also published five books and filed two patents. He has supervised twenty one M. Pharm scholars. He received grant from various govt. agencies/ associations for conducting FDP/seminars/conferences/workshops.

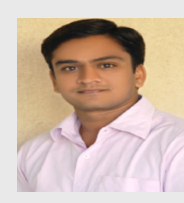

Dr. Swapnil Goyal is presently working as Dean Research and Associate Professor in Department of Pharmacy, B. R. Nahata College of Pharmacy, Mandsaur University, Mandsaur, Madya PradesahIndia. He is having more than 11 years of teaching and research experience. His Research area includes Ethnopharmacology and Immunopharmacology. He published several research articles in national and international journal of repute on the above research area. He published one book also.
\end{abstract}

Cite this article: Sharma S, Sisodiya M, Gautam RK, Goyal S. Columns in Pharmaceuticals: For Primers. Indian J of Pharmaceutical Education and Research. 2020;54(3s):s423-s432. 